\title{
The Effectiveness of Cooperative Learning Model Jigsaw and Team Games Tournament (TGT) towards Social Skills
}

\author{
Saifullah Kamaruddin, Nik Mohd Rahimi Nik Yusoff \\ Faculty of Education, National University of Malaysia, Bangi, Malaysia \\ Email:sbk171211@gmail.com,nik@ukm.edu.my
}

How to cite this paper: Kamaruddin, S., \& Yusoff, N. M. R. N. (2019). The Effectiveness of Cooperative Learning Model Jigsaw and Team Games Tournament (TGT) towards Social Skills. Creative Education, 10, 2529-2539.

https://doi.org/10.4236/ce.2019.1012180

Received: October 16, 2019

Accepted: November 24, 2019

Published: November 27, 2019

Copyright $\odot 2019$ by author(s) and Scientific Research Publishing Inc. This work is licensed under the Creative Commons Attribution International License (CC BY 4.0).

http://creativecommons.org/licenses/by/4.0/

\begin{abstract}
Cooperative learning is a student-centered learning method that allows students to collaborate and interact in small groups. The purpose of this study was to identify the effectiveness of the Cooperative Learning Model Jigsaw and Team Games Tournament towards Year Three student's social skills in Islamic education subjects of hadith. The study was conducted using quantitative methods in the form of quasi experimental studies. The social skills rating scale-teacher (SSRS-T) tests have been tested for their reliability to obtain data on the level of social skills of students. Respondents of the study consisted of a total of 60 national primary school pupils in the district of Nilai, Negeri Sembilan. Respondents consist of 30 students of control group and 30 students of experimental group. Pre-test to test achievement of student's social skills level before treatment and post test to test effectiveness of treatment were conducted. Descriptive and inference analysis were used to test the study questions using the Statistical Packages for the Social Sciences (SPSS) version 23.0. The findings showed that the level of social skills of the treatment group was at a moderate level with a mean score of 3.397 and there was a significant difference in the mean score of social basic skills between the treatment group and the pre group after the post test. This finding is expected to benefit the District Education Office, the State Education Department and the Curriculum Development Division of the Ministry of Education to increase information, to improve the existing Islamic Education pedagogical modules as well as changing the exam oriented pedagogy to skills oriented pedagogy. The enhancement of social basic skills in the aspects of language skills, communication skills and collaborative skills is expected to provide students with satisfaction and happiness.
\end{abstract}

\section{Keywords}

Cooperative Learning Model, Jigsaw, TGT, Student's Social Skills 


\section{Introduction}

Changes in current education policies cause pedagogical methods to be in line with today's demands. The abolition of the first-stage formal examination system in the Education system in Malaysia opens the room for improvement of the classroom assessment system which emphasizes in the progress of pupils holistically and continuously. In addition, the revision of the Kurikulum Standard Sekolah Rendah (KSSR) known as Primary School Standard Curriculum in 2017 has led to a change in terms such as the introduction of the Dokumen Standard Kurikulum Pentaksiran (DSKP) known as Standard Documentary Assessment Curriculum with details emphasizing 21st century skills. Among the 21st century skills included in the curriculum are life skills and career, learning and innovation skills and information technology, communication and media skills (Ministry of Education Malaysia 2018). Student development is no longer measured based on academic achievement but also the development of self-skills such as social skills. Hence, teachers as instructors need to have an effective learning strategy and model to realize the goal of continuously expanding students' potential and improving their existing skills. The cooperative learning model of Jigsaw (CLMJ) and Cooperative Learning Model of Team Games Tournament (CLMTGT) are learning models that can enhance the students' social skills as well as their achievements.

CLM is a strategic learning approach, collecting students in a group activity to achieve the same objective. According to Johnson et al. (1987), cooperative learning should be included by element of positive interdependence, individual accountability, group interaction and social skills. The cooperative learning approach also makes students more motivated and responsible for their learning. The effectiveness of cooperative learning depends on the social skills aspect taught by the teacher. Among them are leadership, decision making, communication skills and conflict management. Overall, cooperative learning has specific policies and principles that can enhance learning, cultivate noble values such as respect, responsibility and contain useful social skills to students (Salha, 2014). Therefore, cooperative learning has a significant influence on student's social skills (Masoud Gholamali Lavasani et al. 2011).

The social skills' variables were chosen given the current educational policy requirements that emphasized the 21 st century skills of students. The development of social emotional competence among primary school's pupils between 7 to 11 years old indicated that there were no statistical differences involving self-awareness, empathy, motivation to communicate and social skills (Tarasova 2016). In addition, the culture of excellence, affection and respect as a spur of education policy in school is also a matter of need to expand. The study of the effectiveness of a learning model is also important to create an enjoyable school climate. This is supported by the study of the school's joyful framework conducted by the UNESCO. The UNESCO study states that the factors of people, process and place are the decisive criteria of a happy school (UNESCO, 2016). 
One way to expand is to create a learning model that has fun learning elements, promoting a culture of affection and respect through classroom learning activities (Ministry of Education Malaysia, 2018). The conceptual teaching of comfort, the application of values and skills should be practiced in the teaching of teachers, especially the Islamic Education Teachers. Thus, this quasi-experimental was conducted to identify the effectiveness of the CLMJ and CLMTGT on the improvement of 3rd year student's social skills in Islamic Education subjects of Hadith.

\section{Problem Statement}

The development of social skills at present is so critical because of the various social problems that hit the community. Reported cases of disciplinary misconduct such as bullying, gangsterism continue to be rampant (Abdul Razak Osman, 2019). Depending on the performance evaluation of the exam will also invite psychological and social impact on the development of student character. The problem of stress and performance comparison between pupils is one of the psychological and social effects that cause hostility among pupils (Somaye Ketabi \& Saeed Ketabi, 2014). The heavy pressure in pursuing grades and achievement through the assessment of the exam also felt the teacher (Tajul Ashikin Jumahat et al., 2013). Moreover, children with social skills deficits in verbal and nonverbal communication can face a variety of social challenges in many aspects of their lives. Given the increasing social needs of many students in today's classrooms, there is a need for increased social skills lesson and support in public schools (Monica St. Amand Santos, 2018).

The implementation of cooperative learning requires only short-term investment by teachers in terms of time and resources (Buchs \& Butera, 2015). This causes the CLMJ and CLMTGT to be used frequently in various subjects in higher education or in school. CLMJ and CLMTGT still involve lesser pupils at the primary school level and in Islamic education subjects. Studies on cooperative learning in Malaysia focuses more on measuring achievement and motivation among students at secondary school (Bhavani Somasundram \& Zamri Mahamod, 2017) and achievement and interest among students at primary school (Nor Amin Lawisau \& Nik Mohd Rahimi Nik Yusoff, 2017). Whereas social skills in Islamic education are essential aspects of emotional intelligence that will determine the student's excellence and useful to the community (Tengku Elmi Azlina et al., 2014). Therefore, the implementation of CLMJ and CLMTGT is essential for Islamic education subject at primary school level because of the needs and the knowledge gap to be fulfilled.

\section{Literature Review}

\subsection{Social Skills}

Classical education theory like behaviorist sees that social skills education is influenced by behavior. Thorndike and Skinner through his magical box experi- 
ment found that animals such as dogs, cats and mice showed a reaction by instrumental conditioning. If reward is given, animal's responses will occur (Zeki Kaya \& Selcuk Akdemir, 2016). This means that repeatition of learning process will lead to human response. Thus, if the rewards are given in learning activities, students will try to learn. The CLM also has a reward element. TGT gives scores to the group in healthy competition and jigsaw has a reinforcing element with the help of a group of friends.

The cognitive development theory of Lee Vygotsky is an important theory to consider in the CLM. According to Vygotsky in his book Mind in society (1978), the thinking of language and the process of reasoning develops through social interaction. The conducive environment, spoken language and the influence of others in the world of children are an important influence in their cognitive and social development stages.

Menwhile, Albert Bandura insists that children tend to imitate the aggressive behavior of the adults around them. The Social Learning Theory proposed by Bandura has emphasized how human behavior is influenced by the environment through reinforcement and imitation learning (Bandura, 1999). According to Bandura, the process of observing and imitating the behavior and attitudes of others as a model is a learning action. This means that in cooperative learning, teacher and peer that demonstrate the right techniques and methods will influence the social skills of a student. Therefore environmental support is necessary to encourage students's engagement and nurture students' inner skill in various learning activities at school (Irwan Fariza Sidik et al., 2018).

\subsection{Cooperative Learning Model Jigsaw (CLMJ)}

The jigsaw was introduced by Elliot Aronson in the early 1970s and was applied in learning by his students at the University of Texas and the University of California. Jigsaw technique has been described in depth through the book Cooperation in the classroom the jigsaw method (Aronson \& Patnoe S, 1978). Jigsaw is one of the cooperative models that make the students expert on the level they are learning. This model is similar to Jigsaw Puzzle. Each member of the group donates a piece of puzzle by sharing some information they are learning. The key to the idea of Jigsaw is that each student in a team will master in a particular chapter and be responsible for teaching what they have learned to friends in the group. The breakdown of the small topic will be divided according to the student's ability. This partnership will encourage interaction and enhance the social skills of students.

Recent studies indicate that Jigsaw has a significance impact on promoting interests among students to engage in social and group interactions (Nur Syaza Farha Diyazid et al., 2017; Thunishaa a/p Veerappen, 2016). The previous study shows that the CLMJ is seen to have an impact on the improvement of student's achievement. Moreover, CLMJ was also effective in improving comprehension and mastery of basic science concepts in the content of physical qualities and measurement topics (Amutha A/P Munia Nendi, 2018). There is also positive 
impact on student's performance in the general certificate of education Advanced-Level Psychology (Nur Hafizah Azmin, 2016). In addition, Jigsaw-based cooperative learnng method also helps engineering students to solve their problems proactively (Dhage et al., 2016).

In CLMJ of learning Islamic education of hadith section, students with good memorization skills are tasked with helping their group remember the text of the hadith. While other members are assigned to master other content or puzzles. Among them are the content of the wisdom of respecting the parents and the love of the young and the consequences of disrespecting the parents and rebellious actions against them. They will then ensure the information and content of the lessons are shared within the respective groups through positive interactions in small groups.

\subsection{Cooperative Learning Model Team Games Tournament (CLMTGT)}

The Cooperative Learning Model Team Games Tournament (CLMTGT) was introduced by Robert Slavin. Theoretically, this model based on two major perspective; motivational and cognitive (Slavin, 1987). CLM is an easy technique that involves the activities of all students without the need for a difference status. TGT involves the role of the student as a tutor or peer (peer counselor) and contains game elements and reinforcement. Learning activities and games planned in cooperative learning in the TGT model enable students to learn more relaxed while cultivating responsibilities, honesty, collaboration, healthy competition and learning involvement (Slavin, 2011).

The TGT principle was originally developed by Davied Devries Keith Edward and was the first method of learning from Johns Hopkins. In doing so, the TGT model will divide students into small groups of 3 to 5 students (Van Wyk, 2011). Divisions differ according to their capabilities, gender, and ethnic background. Pupils will work together in small groups. The TGT concept does not involve the form of quizzes and individual value-enhancing systems. TGT uses an academic game match. In the tournament, students competed to represent their team with other team members who were of the same level of academic achievement. Achievement equations are measured through past academic achievement.

\section{Methodology}

The methodology used in this study covers aspects of design, sample, instrument and data analysis process.

\subsection{Research Design}

The design of this study was a quasi-experimental formulation involving two groups named as treatment groups and control groups. The treatment group uses both the CLMJ and CLMTGT while the control group uses conventional learning techniques. Pre-test and post-test were conducted to identify the effectiveness of CLMJ and CLMTGT on 3rd year student's social skills in Hadith's 
Islamic Education subject. In this study, the CLMJ and CLMTGT were exposed to the treatment group after the pre-test conducted for 8 weeks, each 3 weeks for CLMJ, 3 weeks for CLMTGT and 2 weeks for pre and post-test.

In implementing the CLMTGT in the Islamic Education subject of the Hadith, the pupils will be involved in answering the questions provided. The questions raised are related to the topic of the "Dear young and respectful old" tradition. Each member of the opposing group will ask questions to the same challenger from another group and then they will reply to the other group's reply by question. If the answer is incorrect, the second friend's help can be given and if the answer is correct the group will no longer have a full score. Scores will be given and collected until the end of the competition. The winning group will be rewarded. The form of communication, collaboration and emotional control capabilities through body language skills is a key objective in CLMTGT and is thus able to impact on the development of social skills of students. When pupils are marginalized with CLMTGT and group activities, they will be more confident, brave and more responsible.

\subsection{Research Sample}

The sample of the study involved 60 pupils of third year primary school at Nilai, Negeri Sembilan which were divided equally; 30 for the treatment group and 30 for the control group. Group divisions based on the advice of school administrators with the level of achievement and the students' existing skills who are almost identical.

\subsection{Research Instrument}

Research instrument is taken and adapted from (Zeynep Karatas et al., 2015) known as Social Skills Rating Scale Teacher (SSRS-T). This instrument contains 25 items and can be divided into 3 main skills of social skills. These skills are language skills, skills communication and collaborative skills. Construct of body skills consists of 7 items, 10 items of communication skills and 8 items of common skills. The score of 4 points was used in measuring the level of social skills of the students. This instrument has been tested on its validity and reliability through the Alpha Cronbach test and got the overall reliability value of 0.973 . Based on this test, the value of the instrument reliability score is at a very high level.

\subsection{Data Analysis Procedure}

The data analysis procedure uses the Statistical Package for the Social Sciences (SPSS) version 23. Descriptive and t-test analysis was carried out on the treatment group and the control group. The significant level of decision making is set at 0.05 level. The null hypothesis will be rejected if $\mathrm{P}$ value obtained less than 0.05 and otherwise accepted if the value exceeds the level. In addition, to facilitate the process of analyzing the data, the mean score interpretation of the 
SSRS-T instrument is set as follows: (Table 1)

Quantitative data analysis is then performed using descriptive and inferential statistics. According to Piaw (2006) descriptive statistics are statistics used to describe the characteristics of variables. In this study the variables studied are social skills of students. This descriptive statistic is intended to determine mean, standard deviation, median, mode, frequency and percentage.

\section{Results and Findings}

The choice of data analysis for this study is based on questionnaire as in following Table 2.

\subsection{The Level of Social Skills of the Group of Treatment Groups towards the CLM of jigsaw and TGT}

The first question was analyzed descriptively. The three construct of scores are representing social skills. The construct are language skills, communication skills and student collaborative skills were calculated to obtain the overall mean of pupil's social skills after the intervention was applied to the treatment group. Here is a post test result involving treatment groups: (Table 3 )

Based on the post test results, it is found that the overall mean of social skills level is 3.397 (moderate). While the language proficiency of the body recorded the highest mean score of 3.504. Body language skills items include aspects of following rules, acting on instructions, listening to when someone talks with them, controlling anger, accepting irresponsible criticisms, sensitive to the surrounding events and realizing feelings is 3.397 (moderate).

\subsection{The Mean Differences of Social Skills between Treatment Group and Control Group}

Inference analysis using t-test was performed to answer the research questions. The objective of research is based on following hypothesis:

Hol: There was no significant difference in the social skills of pupils in the Islamic education subjects of the Hadith between treatment groups using cooperative learning model of jigsaw and TGT techniques with control groups using conventional learning model after post-test. The following Table 4 shows the results of mean differences of social skills between treatment group and control group after pre-test and post test.

Table 1. Mean score interpretation (Riduwan 2012).

\begin{tabular}{cc}
\hline Mean Range & Interpretation Score \\
$1.00-1.49$ & Unrelated \\
$1.50-2.49$ & Low \\
$2.50-3.49$ & Moderate \\
$3.50-4.00$ & High \\
\hline
\end{tabular}


Table 2. Research question and data analysis methods.

\begin{tabular}{lc}
\hline \multicolumn{1}{c}{ Research Question } & Data Analysis Methods \\
\hline $\begin{array}{l}\text { What is the level of social skills students of the treatment group to } \\
\text { the Cooperative Learning Model of Jigsaw and TGT? }\end{array}$ & Mean Score \\
$\begin{array}{l}\text { Is there a significant difference in social skills between treatment } \\
\text { groups and control group after post test? }\end{array}$ & t-test \\
\hline
\end{tabular}

Table 3. Post test result of SSRS-T: level of social skills of the treatment group.

\begin{tabular}{ccc}
\hline Construct & Mean Score & Score Interpretation \\
\hline Body Language Skills & 3.504 & High \\
Communication Skills & 3.413 & Moderate \\
Collaborative Skills & 3.274 & Moderate \\
Total Mean Score & 3.397 & Moderate \\
\hline
\end{tabular}

Table 4. The mean differences of social skills and t-value.

\begin{tabular}{cccccc}
\hline Group & $\begin{array}{c}\text { Mean } \\
\text { Pre-Test }\end{array}$ & Post-Test & $\begin{array}{c}\text { Difference } \\
\text { of improvement }\end{array}$ & t-value & Significance \\
\hline $\begin{array}{c}\text { Control } \\
(\mathrm{N}=30)\end{array}$ & 50.9 & 53.96 & 3.06 & 5.122 & 0.000 \\
$\begin{array}{c}\text { Treatment } \\
(\mathrm{N}=30)\end{array}$ & 51.63 & 84.67 & +30.18 & 30.642 & 0.000 \\
\hline
\end{tabular}

Based on Table 4, the mean increase in students' social skills for the group was 3.06. While for the treatment group increased significantly, i.e. 33.24. The difference in the mean increase in the treatment group compared to the control group was 30.18. Based on the t-test, there were significant differences in the level of social skills of both treatment groups and control groups $(P<0.05)$. Hence Hol is rejected.

\section{Discussion}

Based on the findings, it can be concluded that the CLMJ and CLMTGT are very effective in improving the social skills of year three pupils in Islamic Education subjects. This is because the CLMJ and CLMTGT train pupils to be disciplined, environmentally conscious, respecting groups, encouraging interaction, stimulating leadership, responsible attitude and striving to achieve group goals. The emphasis on improving language skills, communication skills and collaborative skills is key to the effectiveness of CLMJ and CLMTGT towards student's social skills. Good social skills involve an effective interaction process as it exists in the CLM. The interaction that occurs when children play can promote collaboration, sharing and problem solving, building respect and appreciating other people's ideas (Azimah Abdullah, 2017). Social skills require good interaction skills and are something to be learned (Norshidah et al., 2018). This finding reinforces the view that social skills are not inherited but through experiences 
and skills that are nurtured from childhood to adulthood (Tengku Elmi Azlina et al., 2014).

Teachers are not denied the factors contributing to this effectiveness. Teachers need to intelligently control their pupils in order to comply with the instructions, to control the situation and behavior of problematic students. Teachers should also communicate verbally, using appropriate body language and body posture in the classroom (Mohd Khairuddin Abdullah et al., 2014). Additionally, teachers need to know the methods of raising student motivation so that they are enthusiastic about the activities being carried out. The materials selection should be suitable for them. In short, the findings give further implications to the daily Islamic education lessons. Communication between students trends to be more active. However, the readiness and firmness of the teachers to control the discipline, motivation to learn, attitudes and behavior of students are the big challenges to overcome.

CLMJ and CLMTGT are also vulnerable to such weaknesses as it requires more preparation time than conventional learning model. But this can be overcome through preparatory work and a true collaboration among Islamic education teachers through collaborative practices. The preparation of Jigsaw materials and TGT can be framed during the workshop on teaching aids among Islamic education teachers and should be shared among daily primary schools. Islamic education teachers also should be given more training and courses on technological pedagogical and content knowledge (TPACK). As a result, their creativity and skills will improve to conduct effective CLM lessons. Therefore, the proposed study on the CLM is necessary for Islamic Education subjects in the Al-quran, aqidah, ibadah, jawi, sirah and adab sections for the benefit of pupils and to promote creative education among the teachers.

\section{Acknowledgements}

This research was supported by the Faculty of Education, Universiti Kebangsaan Malaysia code GG-2019-019 and PP-FPEND-2019.

\section{Conflicts of Interest}

The authors declare no conflicts of interest regarding the publication of this paper.

\section{References}

Abdullah, A. (2017). Kemahiran Kognitif Dan Sosial Kanak-Kanak Autisme Dalam Permainan Numerasi. Penang: University of Science Malaysia.

Abdullah, M. K., Johari, K., Chuchu, A. Y. A., \& Laji, H. (2014). Komunikasi Guru Dalam Bilik Darjah Dan Tingkah Laku Delinkuen Murid Sekolah Menengah, University of Malaysia Sabah, Jabatan Pendidikan Sabah. Jurnal Pemikir Pendidikan, 5, 59-77.

Amutha A/P Munia Nendi (2018). Pendekatan Pembelajaran Koperatif Teknik Jigsaw Bagi Kursus Engineering Science (DBS 1012) in POLISAS. e-Proceedings National Innovation and Invention Competition through Exhibition 2018. 
Aronson, E., \& Patnoe S. (1978). The Jigsaw Classroom (p. 197). Beverly Hills, CA: Sage Publications.

Azmin, N. H. (2016). Effect of the Jigsaw-Based Cooperative Learning Method on Student Performance in the General Certificate of Education Advanced-Level Psychology: An Exploratory Brunei Case Study. International Education Studies, 9, 91-106. https://doi.org/10.5539/ies.v9n1p91

Bandura, A. (1999). A Social Cognitive Theory of Personality. In L. Pervin, \& O. John (Eds.), Handbook of Personality: Theory and Research (pp. 154-196). New York: Guildford Publications. https://doi.org/10.1037//0033-295X.106.4.676

Buchs, C., \& Butera, F. (2015). Cooperative Learning and Social Skills Development (pp. 201-207). New York: Nova Science.

Dhage, J. R., Pawar, A. B., \& Patil, M. S. (2016). Effect of the Jigsaw-Based Cooperative Learning Method on Engineering Students. Journal of Engineering Educations Transformations, Special Issues.

Diyazid, N. S. F., Othman, S., \& Sabil, A. M. (2017). Penggunaan Kaedah Pembelajaran Koperatif Jigsaw II Terhadap Pencapaian Pembelajaran Teks Puisi Tradisional Dalam Kalangan Pelajar Kolej Vokasional. Jurnal Pendidikan Bahasa Melayu; Malay Language Education (MYLEJ), 7, 41-50.

Johnson, D. W., Johnson, R. T., \& Holubec, E. J. (1987). Structuring Cooperative Learning Lessons Plans for Teachers (p. 339). Edina, MN: Interaction Book Company.

Jumahat, T. A., Noor, F. M., \& Ibrahim, M. B. (2013). Faktor-faktor Penentu Stres Dalam Kalangan Guru: Sekolah Rendah Mubaligh di Kuala Lumpur. Jurnal Kurikulum \& Pengajaran Asia Pasifik, 1.

Karatas, Z., Sag, R., \& Arslan, D. (2015). Development of Social Skill Rating Scale for Primary School Students-Teacher Form (SSRS-T) and Analysis of Its Psychometric Properties, July 2015. Procedia-Social and Behavioral Sciences, 197, 1447-1453. https://doi.org/10.1016/j.sbspro.2015.07.093

Kaya, Z., \& Akdemir, S. (2016). Learning and Teaching: Theories Approaches and Models (2nd ed.). Ankara.

Ketabi, S., \& Ketabi, S. (2014). Classroom and Formative Assessment in Second/Foreign Language Teaching and Learning. Theory and Practice in Language Studies, 4, 435-440. https://doi.org/10.4304/tpls.4.2.435-440

Lavasani, M. G., Afzali, L., Borhanzadeh, S., Afzali, F., \& Davoodi, M. (2011). The Effect of Cooperative Learning on the Social Skills of First Grade Elementary School Girls. Procedia-Social and Behavioral Sciences, 15, 1802-1805. https://doi.org/10.1016/j.sbspro.2011.04.006

Lawisau, N. A., \& Yusoff, N. M. R. N. (2017). Pembelajaran Koperatif Model STAD Mata Pelajaran Sejarah KSSR. In National Seminar of Science and Psychology in Education (pp. 332-341).

Ministry of Education Malaysia (2018). Guidelines of Classroom Assessment (PBD) for Pupils Level 1. Putrajaya.

Norshidah, M. S., Manisah, M. A., \& Zainal, K. (2018). Kemahiran Tingkah Laku Sosial Peringkat Asas Dalam Kalangan Murid Berkeperluan Khas Pendidikan Khas Ketidakupayaan Penglihatan. Jurnal Pendidikan Malaysia, 43, 41-49.

https://doi.org/10.17576/JPEN-2018-43.01-06

Osman, A. R. (2019). 122 Pelajar terlibat kegiatan tidak bermoral. Utusan Online. https://theworldnews.net/my-news/122-pelajar-terlibat-kegiatan-tidak-bermoral

Piaw, C. Y. (2006). Kaedah dan Statistik Penyelidikan (325 p.). New York: McGraw-Hill 
Education.

Salha, M. H. (2014). Keberkesanan Pembelajaran Kooperatif Untuk Meningkatkan Motivasi Pelajar Dalam Pembelajaran Bahasa Melayu. In Proceeding of the Global Summit on Education.

Santos, M. St. A. (2018). Generalization of Social Skills Based on Instructional Setting. Walden Dissertations and Doctoral Studies, Minneapolis, MN: Walden University.

Sidik, I. F., Awang, M. M., \& Ahmad, A. R. (2018). Social Environment Support in Various Types of Secondary Schools in Improving Soft Skills among Students. Jurnal Pendidikan Malaysia SI, 1, 67-76. https://doi.org/10.17576/JPEN-2018-43.03-08

Slavin, R. E. (1987). Developmental and Motivational Perspectives on Cooperative Learning: A Reconciliation. Child Development, 58, 1161-1167. https://doi.org/10.2307/1130612

Slavin, R. E. (2011). Student Team Learning: A Practical Guide to Cooperative Learning. Washington DC: National Education Association.

Somasundram, B., \& Mahamod, Z. (2017). The Effectiveness of Cooperative Learning towards Achievement and Motivation Secondary School in Malay Language Learning. Jurnal Pendidikan Bahasa Melayu, 7, 11-23.

Tarasova, K. S. (2016). Development of Socio-Emotional Competence in Primary School Children. Procedia-Social and Behavioral Sciences, 233, 128-132.

https://doi.org/10.1016/j.sbspro.2016.10.166

Tengku Elmi Azlina, T. M., Syazarina, D. A., Ishak, M. F., \& Ahmad Syafiq, M. R. (2014). Kemahiran Sosial Menurut Perspektif Islam: Aplikasinya Dalam Membentuk Keperibadian Pelajar. Jurnal Pendidikan, 1, 42-56.

Thunishaa a/p Veerappen (2016). Perbandingan Keberkesanan Kaedah Pembelajaran Koperatif Model Jigsaw Bagi Tajuk Bumi, Bulan dan Matahari. Tanjong Malim: Universiti Perguruan Sultan Idris.

United Nations Educational, Scientific and Cultural Organization (UNESCO) (2016). Happy Schools a Framework for Learner Well-Being in Asia Pacific. Bangkok: Asian and Pacific Regional Bureau of Education.

van Wyk, M. M. (2011). The Effects of Team Games Achievement, Retention, and Attitudes of Economics Education Students. Journal of Social Sciences, 26, 183-193.

https://doi.org/10.1080/09718923.2011.11892895 